\title{
FOOD INSECURITY AMONG INTERNATIONAL POST-SECONDARY STUDENTS STUDYING ON A CANADIAN CAMPUS: A QUALITATIVE DESCRIPTIVE STUDY
}

\author{
MAHITAB HANBAZAZA \\ KING ABDULAZIZ UNIVERSITY \\ GEOFF DC BALL \\ UNIVERSITY OF ALBERTA
}

\author{
MARYAM KEBBE \\ LOUISIANA STATE \\ UNIVERSITY \\ ANNA PFARMER \\ UNIVERSITY OF ALBERTA \\ NOREEND WILLOWS \\ UNIVERSITY OF ALBERTA
}

\author{
ARNALDO PEREZ \\ UNIVERSITY OF ALBERTA
}

KATERINA MAXIMOVA

UNIVERSITY OF TORONTO

\begin{abstract}
Enrollment of international post-secondary students is increasing across Canadian campuses. International post-secondary students may experience challenges in accessing nutritious foods that meet their dietary needs and food preferences. These challenges can pose negative impacts on their health, well-being, and academic achievement. Our aim was to describe international post-secondary students' perceptions of (1) challenges to attaining food security and (2) consequences of food insecurity on the university experience. We conducted individual semi-structured interviews with 11 international post-secondary students who had food insecurity, were enrolled at a public university in Canada, and who had requested emergency food hampers from the on-campus food bank. Interviews were audio-recorded, transcribed verbatim, and analyzed using manifest, inductive content analysis. International post-secondary students reported several logistical issues related to obtaining sufficient food, including a lack of time, limited family support, modest food preparation skills, and low knowledge about supportive services and resources. Students also faced challenges in sourcing culturally appropriate foods, including issues related to food availability, accessibility, acceptability, and affordability. Further, they perceived food insecurity to negatively influence their academic performance through compromised concentration, reduced class and exam attendance, and adverse impacts on physical, mental, and social well-being. Some students reported extreme food deprivation, resulting in hunger. Our results revealed the negative impacts that food insecurity can have on international post-secondary students. Findings underscore the imperative to minimize the occurrence of food insecurity while studying in Canada by introducing and enhancing support systems on campus and in the community to enable food security.
\end{abstract}

Keywords: academic performance, Canada, food insecurity, students, qualitative research

\section{Résumé}

Les inscriptions d'étudiants internationaux augmentent sur les campus canadiens. Les étudiants internationaux de niveau postsecondaire peuvent vivre certaines difficultés pour accéder à des aliments nutritifs qui répondent à leurs besoins et préférences alimentaires. Ces défis peuvent avoir des effets négatifs sur leur santé, leur bien-être et leurs résultats scolaires. Notre objectif était de décrire les perceptions de ces étudiants en ce qui concerne (1) les défis pour atteindre la sécurité alimentaire et (2) les conséquences de l'insécurité alimentaire sur l'expérience universitaire. Nous avons mené des entrevues individuelles semi-structurées avec 11 étudiants internationaux de niveau postsecondaire qui souffraient d'insécurité alimentaire, qui étaient inscrits dans une université publique au Canada et qui avaient demandé des paniers alimentaires d'urgence à la banque alimentaire de leur campus. Les entretiens ont été enregistrés en audio, transcrits mot pour mot, 
et fait l'objet d'une analyse de contenu manifeste et inductive. Les étudiants internationaux de niveau postsecondaire ont signalé plusieurs problèmes logistiques liés à l'acquisition de nourriture, notamment un manque de temps, l'absence de soutien familial, des compétences culinaires faibles et une faible connaissance des services et des ressources de soutien. Les étudiants disent également avoir été confrontés à des défis pour se procurer des aliments culturellement appropriés, y compris des problèmes liés à la disponibilité, à l'accessibilité, à l'acceptabilité et au prix des aliments. De plus, ils disent percevoir une influence négative de l'insécurité alimentaire sur leurs résultats scolaires à cause d'une concentration moindre, d'une réduction de la fréquentation des cours et des examens et des effets néfastes sur le bien-être physique, mental et social qu'elle entraîne. Certains étudiants ont signalé une privation alimentaire extrême entraînant la faim. Nos résultats ont révélé les effets négatifs que l'insécurité alimentaire pouvait avoir sur les étudiants internationaux de niveau postsecondaire. Les résultats soulignent l'impératif de minimiser l'occurrence de l'insécurité alimentaire pendant les études au Canada en introduisant des systèmes de soutien sur les campus et dans la communauté pour permettre la sécurité alimentaire et en améliorant ceux qui existent.

Mots-clés : réussite universitaire, Canada, insécurité alimentaire, étudiants, recherche qualitative

\section{Introduction}

International foreign students are important to Canada's general economy and to the economic sustainability of post-secondary institutions. Since graduation from a Canadian post-secondary institution is a pathway to permanent residency, Canada is an attractive location for international students to pursue their foreign education. Indeed, 53,700 international students became permanent residents of Canada in 2018, helping to drive economic growth as both workers and consumers (Government of Canada, 2020a). In early 2020, more than 640,000 international post-secondary students studying in Canada were contributing $\$ 22$ billion annually to the economy and supporting $~ 170,000$ jobs (El-Assal \& Thevenot, 2020). The higher tuition fees paid by international post-secondary students compared to domestic students contribute substantially to the revenue streams of Canadian universities (Anderson, 2015).

Countering the economic significance of international post-secondary students in Canada to Canadian post-secondary institutions and the Canadian economy at large, these students often endure a high likelihood of food insecurity, as in other Very High Human Development Index countries (Lee et al., 2018). In addition, the COVID-19 pandemic may have increased food insecurity among post-secondary students, many of whom have lost jobs and access to on-campus food services (Laban et al., 2020). As defined by the Government of Canada, food insecurity is "the inability to acquire or consume an adequate diet quality or sufficient quantity of food in socially acceptable ways, or the uncertainty that one will be able to do so" (Government of Canada, 2020b). At the household level, food insecurity is often linked with the household's financial inability to access adequate food. Unique circumstances contributing to food insecurity among international post-secondary students are likely due to financial constraints associated with higher tuition fees (Lee et al., 2018; Olauson et al., 2018) and visa restrictions that limit employment opportunities to earn supplemental income (Frank, 2018; Olauson et al., 2018; Sanchez-Serra \& Marconi, 2018). Our previous work to understand the reasons for food insecurity and its consequences in international post-secondary students attending a large, public university in western Canada found that insufficient income to meet the high costs of obtaining a foreign education was the predominant reason for their food insecurity (Farahbakhsh, 2015). Contributors to international students' financial hardship included not receiving financial support from the foreign institution of study, paying high international tuition fees and living expenses, credit card debt, and family funding or graduate student assistantships that were inadequate to cover the costs of education. International post-secondary students also had fewer strategies to cope with food insecurity compared to domestic students (Farahbakhsh et al., 2015).

While economic access to food is an important aspect of food insecurity for international students, the pillars of food insecurity that expand beyond economic aspects are often overlooked. For example, some international students may be fully responsible for their food choices for the first time, which may alter their eating habits (Papadaki et al., 2007). Similar to other immi- 
grants in Canada, international post-secondary students may also face challenges in finding acceptable foods that meet religious requirements and cultural food preferences (Aljaroudi et al., 2019). Regardless of the cause, international post-secondary students who experience food insecurity are likely susceptible to the same range of negative academic, nutritional, and physical and mental health outcomes associated with food insecurity among domestic students, including the inability to cover basic needs, persistent worry about not having sufficient food, disrupted learning, and negative impacts on social life (Bruening et al., 2017; Entz et al., 2017; Frank et al., 2018; Jyoti et al., 2005; Lee et al., 2018; Maroto et al., 2015; Mhurchu et al., 2010; Morris et al., 2016).

Further research on international post-secondary students' experiences with food insecurity is instrumental to inform policy decisions to enhance positive experiences of studying in Canada and to aid in the development of strategies to reduce food insecurity and the impact of food insecurity. Among international post-secondary students experiencing food insecurity, we describe responses to qualitative interview questions related to (a) challenges to attaining food security and (b) consequences of food insecurity on the university experience.

\section{Methods}

\section{Study Design}

This qualitative descriptive study of food insecurity among international post-secondary students took place at the University of Alberta, Canada. Qualitative descriptive studies aim to provide a comprehensive summary of events in the everyday terms of those events; this design was suited to gather direct, practical insights from international post-secondary students in relation to food insecurity that can be used by post-secondary policy makers without requiring detailed interpretive interference (Sandelowski, 2000). The study was approved by the Board of Directors and Executive Director of the Campus Food Bank as well as the Health Research Ethics Board (Pro00040231) at the University of Alberta.

\section{Participants}

Purposive sampling was used to obtain information-rich cases on international post-secondary students experi- encing food insecurity studying at the University of Alberta (Sandelowski, 2000). We recruited participants from those who had participated in an existing quantitative study on student food insecurity and indicated their willingness to participate in in-depth interviews about their experiences with food insecurity (Farahbakhsh, 2015); participants who consented were contacted through provided emails to confirm their willingness to participate. To be included in the study, participants had to (a) be international post-secondary students without children in their care, (b) have requested and received emergency food relief from the on-campus food bank, and (c) have been confirmed as having food insecurity in our previous quantitative study using the 10-item USDA Adult Food Security Survey Module (United States Department of Agriculture, 2020). Students with children in their care were excluded, given the unique food security considerations experienced by families with children (McIntyre et al., 2003).

\section{Data Collection}

Data were collected through individual, semi-structured interviews that elicited international post-secondary students' experiences with food insecurity. Expert members of the research team in diet, nutrition, food insecurity, population health, and the broader literature on this topic developed the interview guide. The interview questions were then pilot tested with four international post-secondary students studying nutrition at the graduate level who were recruited via convenience sampling; this process helped to identify any limitations of the interview questions and understand how participants might interpret and answer each question (Creswell, 2012). Graduate students were chosen because the majority of international students accessing the food bank on campus were studying at this level. Following these pilot interviews, minor editorial changes and refinements were made to improve clarity, readability, and sequencing of the interview questions.

We previously reported on qualitative findings from these interviews related to students' (a) reasons for using the campus food bank services, (b) feelings about using the campus food bank, (c) experiences with the food hamper they received from the campus food bank, and (d) coping strategies students used to deal with food insecurity (Farahbakhsh et al., 2015, 2017; Hanbazaza et al., 2016, 2017). Herein, we focus on responses to 
questions related to (e) challenges to attaining food security and $(f)$ consequences of food insecurity on the university experience.

Between October 2013 and April 2014, one researcher, herself an international graduate student at the time the study was conducted, met all participants individually in a private setting on campus. Probing questions and prompts were used to encourage participants to provide more in-depth responses to the questions. Interviews were 45-60 minutes in duration, audio-recorded, and transcribed verbatim. For accuracy, a second researcher listened to five interview recordings and compared each one with the accompanying transcript. Sociodemographic and educational data (e.g., student status) were collected for descriptive purposes. All data were stored on a secure, password-protected computer at the University of Alberta. Identifying information (e.g., name, ethnicity, country of origin, etc.) were removed to ensure anonymity. Participants were compensated for their time with a CAD $\$ 35$ gift card to a local grocery store. Informed and written consent was obtained from participants before data were collected.

\section{Data Analysis}

Descriptive statistics were used to characterize participants' educational and sociodemographic information. Conventional content analysis at the manifest level was used to analyze the qualitative data (Elo \& Kyngäs, 2008); data collection was done on a concurrent basis with data analysis until data saturation was achieved; that is, when no new categories emerged from the data analysis (Creswell, 2012). The first author (MH) read and re-read transcripts for familiarization with the data. Data segments (e.g., words and phrases) concerning challenges to attaining food security and consequences of food insecurity on the university experience were then coded inductively. Following this, refined codes were applied to the entire data set with new codes developed iteratively when necessary. Similar codes were then sorted into categories, both of which were reviewed and consolidated by the second and third authors (MK, AP). Peer debriefing to review data coding and analysis was done to increase credibility (Holloway, 1997). Supporting quotes are provided for each category and sub-category.

\section{Results}

In total, 11 international post-secondary students (mean age: 24.5 years [range: $18-33$ years]; eight females, three males) participated in the study. Most students (63.7\%) had income from research assistantships or from family. The remaining students received scholarships or bursaries $(9.1 \%)$, had savings $(9.1 \%)$, other employment income $(9.1 \%)$, or other income $(9.1 \%)$. Students were full-time students from Asian $(n=6)$ and non-Asian $(n=$ 5) countries in Europe and the Middle East. Participants were mostly enrolled in graduate studies $(n=6)$, single (not married or cohabitating with a partner; $n=9$ ), and living with others $(n=7)$. Among the seven participants living with others, most $(n=5)$ lived with someone other than a family member or relative and shared the cost of food or meals. Below, we describe the categories and sub-categories related to challenges to attaining food security and consequences of food insecurity on the university experience.

\section{Challenges to Attaining Food Security}

In terms of the challenges to attaining food security, two categories emerged: (a) logistical issues and (b) obtaining culturally appropriate food. Students reported several logistical challenges to attaining food security including a lack of time, a lack of family support, limited information about services and resources, and unemployment/ under-employment. Further, barriers preventing students from acquiring cultural foods on a regular basis were related to availability, accessibility, acceptability, and affordability.

\section{Logistical Issues}

Lack of time. Time limitations were a challenge to attaining food security for nine students. Students mentioned being enrolled full-time at university, thereby spending most of their time attending classes and studying. These commitments challenged the preparation of healthy and cultural meals as students perceived they had limited time available for cooking. Some students reported that when time was limited, they opted for quick, convenient foods as opposed to more time-consuming familiar and cultural foods ("For me, it was difficult at the beginning because my school was really busy and there was not enough time even to cook, so I usually cooked 
something really fast or made a sandwich and took it for lunch" [\#3]), or they did not prepare cultural foods ("For example, to cook appropriate soup as borscht you have to spend like two hours. Once you are studying, it is too much time because you are studying 24 hours a day" [\#10]).

Lack of family support. Six students reported challenges related to living away from their families; in particular, not having their support for assistance with grocery shopping and meal preparation. One student shared,

There is no one here for us, like no parents, no family members, so we cannot expect, like you know, prepared food coming from home or something. You know how to make it, but can't if you don't have time. We're just by ourselves. (\#6)

Other students indicated that the absence of family and close friends meant that they could not turn to them for food, if they ran out of food: "Challenges as an international student, I would say you don't really have much relatives and friends when you run out you could go to. The lack of family support" (\#1).

\section{Limited information about services and resourc-}

es. Three students reported that they were unaware of services and resources available to support them. They were also unaware whether they could benefit from such services and resources as international students without permanent residency or a Canadian citizenship. As one student stated,

I would say as international students, we are not aware of other sources that may be offered to residents but we may also not be able to access those [services and resources] because we are not residents [or Canadian citizens], so that is also another factor. (\#1)

Students suggested that it would be important to inform international students about nearby grocery stores that sell cultural foods, transport information for how to get there, as well as food services around campus and in the city. They perceived guidance to preparing healthy and culturally appropriate meals using foods available in Canada to be beneficial. In addition, they suggested that universities design nutrition education interventions to improve skill development for using financial and food resources as effectively as possible in order to improve food security.

Unemployment/Under-employment. Two students mentioned that finding a job due to being an international student was a challenge to attaining food security. Their student visa restrictions limited where and how much they could work, and jobs prioritized those with a Canadian citizenship. For example:

Most of the time I was trying to find some opportunity to get some money like to work somewhere but unfortunately, as an international student, it is very hard to find some jobs, even as a waitress it is hard...I have been looking this year but again as an international student, it is very hard to find something because first they accept [Canadian] citizenship and primary resident. (\#10)

\section{Obtaining Culturally-Appropriate Food}

Lack of availability of culturally-appropriate foods. Eight students experienced challenges securing culturally-appropriate foods that they are accustomed to finding in most grocery stores in their country of origin. A student stated,

I could not find the food that I am accustomed to even in the farmer's market-even there it is not available. You may find some of the stuff at the Chinese market, you find some of the stuff there, but it's not widely available in the local supermarket.... For example, say fish and chicken foot, what else they have there, and green banana and a lot of stuff that has the taste that I am accustomed to-you are more likely to find it in a Chinese store than say in an American supermarket. (\#1)

Limited accessibility to sources of cultural foods. Two students considered cold weather during the winter as a barrier to purchasing food when needed. In addition, physical inaccessibility to grocery stores and restaurants that sell cultural foods was a barrier for eight students as a result of the distance and time required for access, especially without a car or when using public transit. The following comments support this point:

I have to get something from the store which is far away from my home and I use transportation in the 
cold weather. I use public transportation-it's not very convenient. I usually go to the nearest [grocery store] which is a western supermarket, to buy food. It is western food so I have to eat it, otherwise I need to take a long trip to a Chinese supermarket. (\#9)

Just distance of travel to get the food I want. It is really far away. Like usually I have to go to Mill Woods or somewhere to get culturally appropriate food and that really take time. It takes the whole day, you have to change two buses and go there and come back change two buses. (\#7)

Unacceptability of non-cultural foods. Five students reported that the quality, taste, and smell of foods available in Edmonton, Alberta are different from foods they are accustomed to in their countries of origin. Notably, taste was an important factor that influenced students' food choices, whereby some rejected local foods that did not match their own cultures' palates (\#2). Two quotes illustrating this point are:

I miss some of the food that I am accustomed to back home. Not necessarily the food, but the way it has been prepared, the spices, and other sauces, but here you don't really find, you don't get the same taste... that is the main challenge, it is just the taste of the food. Depending on how some food taste, you may not want to eat it and that would affect the amount that you eat. (\#1)

I think Canadians eat a lot cheese and butter and some sauce I never heard of it...they are already included it in the food I buy, it has the flavour and spices, so I have to eat the food because it's already there.... Even the Asian food, like rice or noodles or spices, they are not Asian spices or Asian rice. (\#9)

Lack of affordability of culturally-appropriate foods. Nine students reported that even if they found culturally-appropriate and preferred foods, they were unable to afford them. They commented that the price of cultural foods was expensive compared to those in their home country. A student mentioned,

Because of scarcity, then it also affects the price, so you find it more expensive than say the normal food on sale so. I would say it is a challenge to get access to the food that you are accustomed to at the price that is affordable. (\#1)

\section{Consequences of Food Insecurity on the University Experience}

In terms of consequences of food insecurity on the university experience, two categories emerged: (a) impaired academic performance and (b) negative well-being. These encompassed a lack of concentration, missing classes and exams, and having a negative physical, mental, and social state.

\section{Impaired Academic Performance}

Lack of concentration. Nine students mentioned that they perceived a lack of food to have a negative influence on their ability to concentrate on their schoolwork, focus during lectures, and be successful in writing exams. A student stated,

When I don't have enough money to buy food or the food are all fresh not to bring to school or eat it as a snack, I feel while I get hungry I cannot concentrate to study. I also get very impatient sometimes a little bit angry while I am in class and that distract me a lot.... When I get hungry sometimes in class, I feel like I want to get out of the class but not happen during exam because I will be worry enough. So, I have to eat a lot to concentrate and study. (\#9)

Missing classes and exams. Nine students mentioned that lack of food had a negative influence on class attendance and attendance at midterm exams, sometimes because of extreme food deprivation. A student stated:

Like I would say my university experience is not going so good...I don't know, I have withdrawn from a course. I don't know how indirectly or directly [food] affected [my withdrawal]. Yes, I had stress and stuff, I did not go to my midterm and then a final [exam] was coming in and at that time, I had withdrawn from the course because I was aware that I will fail that course. I used to starving for food sometimes and I cannot concentrate....and as you are not eating proper food... you don't feel [well enough/energized] to study. (\#6) 


\section{Negative Well-being}

Negative physical well-being. Two students in our study commented on the relationship between extreme food deprivation and hunger. This state of hunger had physical implications, such as feeling weak, cold, and lacking in energy. One student exclaimed,

If I am gonna go hungry, if I have a small portion of food for lunch or dinner at that moment, I might feel ok. It is not a big deal. In one hour, I am gonna start to feel hungry, I am gonna start to feel cold. Sometimes, usually my feet, my foot gets cold, so that is basically a sign of losing temperature because there is not enough sugar in your blood. (\#8)

Negative mental well-being. Seven students reported that not having enough food had negative psychological impacts, leading to feelings of "anger," "stress," "worry," "impatience," and "anxiety." As one student shared, "I also have to worry tomorrow what I am going to eat and what time I am going to cook and I have to plan everything and the thing is getting worse when I don't have any food" (\#11). Two students discussed how their chronic concerns about having enough to eat created stress and worry in their life, stating "I am always thinking about food that you know, I have foods for the week or for tomorrow or for breakfast what I am gonna do for breakfast?... And you know it's extra stress for you to deal with" (\#5), and "I keep worrying oh what I am going to eat for tomorrow, like for 2 weeks what I am going to eat, like I am starving" (\#11).

Negative social well-being. One student indicated that food insecurity prevented her from engaging in daily social activities, including interactions with her friends. She related her experience of social withdrawal due to a lack in energy, explaining “You don't feel to go and socialize with people because you don't have the energy" (\#6).

\section{Discussion}

The findings of this qualitative study provide important information about challenges to attaining food security and consequences of food insecurity on the university experience among international post-secondary students studying in Canada. A main contributing factor to post-secondary students' difficulties in accessing food is inadequate and precarious finances (Lee et al., 2018). The findings of our study indicate that international post-secondary students have unique circumstances that create financial stressors because of visa restrictions on employment and difficulties in finding a job. In Canada, visa regulations stipulate that only full-time international post-secondary students with a study permit can work. These students can work full-time during school breaks, but are restricted to working no more than 20 hours per week during a regular academic session without the need to apply for a separate work permit (ICEF Monitor, 2014). Our interview data suggest that loosening employment restrictions might help some international post-secondary students to achieve food security by permitting them to work more hours while attending university. However, it is important to consider the possibility that working more than 15 hours per week may affect students' academic performance as it may limit time to study, sleep, and prepare healthy foods (Carnevale \& Smith, 2018).

Aside from the financial barriers, post-secondary students experience many non-financial contributors to food insecurity, such as a lack of time for grocery shopping and food preparation, which negatively affect their eating practices (Deliens et al., 2014; Entz et al., 2017; Maynard et al., 2018). As previously reported, international students consume fewer home-cooked meals and more convenience foods than domestic students (Stewin, 2013). Our study corroborates these findings and further suggests that non-financial contributors to food insecurity are heightened in international post-secondary students. These disparities may be an outcome of living far away from home, family, and friends and managing new food-related responsibilities independently, leading to a change in their eating habits.

International post-secondary students in our study also struggled with food appropriateness, which refers to the alignment between the available food and the food preferred for religious, cultural, and ethnic reasons (Pinstrup-Andersen, 2009; Stewin, 2013). International post-secondary students, similar to immigrants in Canada, may not be able to access preferred cultural or religious foods as a result of acculturation and dietary acculturation challenges (Aljaroudi et al., 2019), such as unfamiliarity with local foods and services (Booth \& Smith, 2001; Calder et al., 2016; Chaparro et al., 2009; 
Davis, 2010; Gallegos et al., 2014; Kim, 2001). Many factors influence students' decisions to preserve familiar diets, including availability, time, budget, convenience, and taste preferences, which are shaped by cultural and religious identities (Horacek \& Betts, 1998). In our study, finding cultural foods proved challenging for students from non-European countries, some of whom travelled long distances to obtain preferred foods. In this light, it is not only important to reduce hunger among international post-secondary students, but to do so by maintaining cultural identity with traditional foods, thus improving the acculturation experiences (Amos \& Lordly, 2014; Pinstrup-Andersen, 2009; Power \& Dietitians of Canada, 2005). A previous study indicated that the availability of food from a student's country of origin may alleviate feelings of anxiety and isolation (Brown et al., 2009). In addition, researchers have suggested that to enhance student's acculturation, universities should develop programs that allow international students to feel engaged socially, culturally, and academically (Wu et al., 2015).

A lack of awareness of support programs and food resources is an established barrier to accessing food among recent immigrants to Canada (Vahabi \& Damba, 2013). Our findings also underscore the need to increase internationals students' awareness of services, resources, and foods available to them on campus and in the community. When they first register with the food bank at the University of Alberta, international students are informed about the possibility of receiving emergency loans or financial aid through the International Centre on campus; yet, our results reveal that some international post-secondary students were unaware of these options. Participants also indicated that they did not know about other services on campus for international students to learn about Canadian food culture, receive information about internationalization opportunities, and receive financial, intercultural, and interpersonal support that might help to enable food security (Farahbakhsh et al., 2015; Hanbazaza et al., 2017). It follows that while international post-secondary students require support and services that can help them to optimize their health and well-being, which includes achieving and maintaining food security, additional efforts may be needed to promote, advertise, and tailor such resources and services in order to reach them.

In Canada, tuition fees and unemployment are associated with higher food bank usage among students
(Silverthorn, 2016); post-secondary students can access free emergency food relief at many universities and colleges from charitable agencies such as food banks (pantries) to cope with food insecurity (Silverthorn, 2016). All international post-secondary students in our study had accessed emergency food relief from the food bank located on campus. Unfortunately, food banks are unlikely to ensure food appropriateness (i.e., alignment with culture-specific foods), an important dimension of food insecurity, as they mainly distribute donated foods that are not always appropriate for culturally and ethnically diverse students, including international post-secondary students (Loopstra \& Tarasuk, 2012). Further, as attested by students in our study, food banks have limited potential to resolve food insecurity in their local communities since they do not address financial hardship, the underlying issue that initially leads to food insecurity (Tarasuk et al., 2014).

Food insecurity among post-secondary students can contribute to reduced academic performance (Lee et al., 2018). International post-secondary students in the present study mentioned that food insecurity had a negative influence on their ability to concentrate on their schoolwork, focus during lectures, and be successful in writing exams because of hunger or anxiety about their lack of food. Similarly, previous studies from our group showed that post-secondary students with severe food insecurity reported an inability to concentrate in class and study for exams, as well as failing or withdrawing from courses (Farahbakhsh et al., 2015; Hanbazaza et al., 2017). In a study conducted in the United States, $23 \%$ of students who experienced food insecurity had even further exacerbated responses, where food insecurity compromised/ suspended their studies (Gallegos et al., 2014).

Negative health outcomes of food insecurity among post-secondary students include sub-optimal overall health, poor mental health, and high levels of stress (Davison et al., 2015, 2017; Farahbakhsh et al., 2017; Maynard et al., 2018; Muldoon et al., 2013; Patton-López et al., 2014; Pryor et al., 2016). Some of these outcomes are related to students' experiences of acute hunger, skipping meals, or reduced portion sizes due to food insecurity (Bessey et al., 2020). Food insecurity similarly had negative physical and psychosocial impacts on international post-secondary students in our study who reported weariness and diminished body temperature because of hunger, as well as anger arising from feel- 
ings of hunger. They also reported that a lack of financial resources created psychological suffering in the form of stress and anxiety, potentially exacerbating anxiety about their studies. These findings further highlight the reality that food insecurity is not only about food-it also includes negative physical and psychosocial consequences that result from chronic worry related to not having enough food to eat.

Several limitations regarding this research warrant consideration. While our semi-structured interviews provided rich information about international post-secondary students' lived experiences with food insecurity, these were limited to a sample of students at one university and may not be applicable in other academic institutions. As with any qualitative research, the results we obtain refer to perceptions of the sample under study, as opposed to objective, quantifiable data. Also, in conceptualizing this study, we set out to explore consequences of food insecurity on the university experience, potentially omitting other consequences of relevance among international post-secondary students experiencing food insecurity. Nevertheless, the findings are based on the real narratives of international post-secondary students, who willingly expanded on consequences beyond academic performance (i.e., well-being). Collectively, these narratives are important to consider in establishing or refining programs and services at post-secondary, provincial, and federal levels designed to address food insecurity.

\section{Conclusions}

Given the important financial and non-financial contributions such as internationalization that international post-secondary students make to Canadian campuses, universities hold some social responsibility in ensuring their success (El Masri, 2020). The findings of this study indicate that international post-secondary students experience unique financial and non-financial factors that contribute to food insecurity and that insufficient food and food deprivation negatively influenced their health and academic performance. Creating a campus environment that addresses food security could contribute to improved student satisfaction, diet, and health, thereby facilitating academic success. Universities should therefore consider focusing on the needs and concerns of international students in first-year orientation programs and carefully plan to help international students adapt to their new food environment. Solution-based strategies include implementing on-campus interventions for international post-secondary students such as providing dining card discounts and community kitchens, as well as free-of-charge workshops on budgeting, cooking, grocery shopping, and time management skills. Information about existing cultural food stores and food services around campus and in the city would be beneficial. Funding policies to reduce food insecurity, such as eliminating or minimizing differential tuition fees, creating affordable student housing, and increasing eligibility for Canadian scholarships, may be desirable and beneficial ways to attract more fee-paying international students, build the economic knowledge economy, and contribute to social justice (El Masri, 2020).

\section{References}

Aljaroudi, R., Horton, S., \& Hanning, R. M. (2019). Acculturation and dietary acculturation among Arab Muslim immigrants in Canada. Canadian Journal of Dietetic Practice and Research, 80(4), 172-178. https://doi.org/10.3148/cjdpr-2019-008

Amos, S., \& Lordly, D. (2014). Picture this: A photovoice study of international students' food experience in Canada. Canadian Journal of Dietetic Practice and Research, 75(2), 59-63. https://doi. org/10.3148/75.2.2014.59

Anderson, T. (2015). Seeking internationalization: The state of Canadian higher education. Canadian Journal of Higher Education, 45(4), 166-187. https://doi.org/10.3148/75.2.2014.59

Bessey, M., Frank, L., \& Williams, P. L. (2020). Starving to be a student: The experiences of food insecurity among undergraduate students in Nova Scotia, Canada. Canadian Food Studies, 7(1), 107-125. https://doi.org/10.15353/cfs-rcea.v7i1.375

Booth, S., \& Smith, A. (2001). Food security \& poverty in Australia - Challenges for dietitians. Australian Journal of Nutrition and Dietetics, 58(3), 150-156. https://dietitiansaustralia.org.au/wp-content/uploads/2016/12/58-3-review-paper.pdf

Brown, L., Edwards, J., \& Hartwell, H. (2009). A taste of the unfamiliar. Understanding the meanings 
attached to food by international postgraduate students in England. Appetite, 54(1) 202-207. https:/l doi.org/10.1016/j.appet.2009.11.001

Bruening, M., Argo, K., Payne-Sturges, D., \& Laska, M. N. (2017). The struggle is real: A systematic review of food insecurity on postsecondary education campuses. Journal of the Academy of Nutrition and Dietetics, 117(11), 1767-1791. https://doi. org/10.1016/j.jand.2017.05.022

Calder, M. J., Richter, S., Mao, Y., Burns, K. K., Mogale, R. S., \& Danko, M. (2016). International students attending Canadian universities: Their experiences with housing, finances, and other issues. Canadian Journal of Education, 46(2), 92-110. https://doi. org/10.47678/cjhe.v46i2.184585

Carnevale, A. P., Smith, N. (2018). Balancing work and learning: Implications for low-income students. Georgetown University Center. https://1gyhoq479ufd3yna29x7ubjn-wpengine.netdna-ssl.com/ wp-content/uploads/Low-Income-Working-LearnersFR.pdf

Chaparro, M. P., Zaghloul, S. S., Holck, P., \& Dobbs, J. (2009). Food insecurity prevalence among college students at the University of Hawai'i at Mānoa. Public Health Nutrition, 12(11), 2097-2103. https:/l doi.org/10.1017/S1368980009990735

Creswell, J. W. (2012). Educational research: Planning, conducting, and evaluating quantitative and qualitative research (4th ed.). Pearson.

Davis, J. (2010). Food security and community gardening in the Ashburton, Ashwood and Chadstone neighbourhood renewal area project report. VicHealth.

Davison, K. M., Gondara, L., \& Kaplan, B. J. (2017). Food insecurity, poor diet quality, and suboptimal intakes of folate and iron are independently associated with perceived mental health in Canadian adults. Nutrients, 9(3), 274. https://doi.org/10.3390/ nu9030274

Davison, K. M., Marshall-Fabien, G. L., \& Tecson, A. (2015). Association of moderate and severe food insecurity with suicidal ideation in adults: National survey data from three Canadian provinces. Social
Psychiatry and Psychiatric Epidemiology, 50(6), 963-972. https://doi.org/10.1007/s00127-015-10181

Deliens, T., Clarys, P., De Bourdeaudhuij, I., \& Deforche, B. (2014). Determinants of eating behaviour in university students: A qualitative study using focus group discussions. BMC Public Health, 14(1), 1-22. https://doi.org/10.1186/1471-2458-14-53

El-Assal, K., \& Thevenot, S. (2020, May 14). Canada announces major study and work visa change for fall 2020. CIC News. https://www.cicnews. com/2020/05/canada-announces-major-studyand-work-visa-change-for-fall-2020-0514355. htm|\#gs.8qey3v

El Masri, A. (2020). International education policymaking: A case study of Ontario's Trillium Scholarship Program. SOURCE Scholarly Output Research Creative Excellence. https://source.sheridancollege. ca/nonfaculty cei_publications/8

Elo, S., \& Kyngäs, H. (2008). The qualitative content analysis process. Journal of Advanced Nursing, 62(1), 107-115. https://doi.org/10.1111/j.13652648.2007.04569.x

Entz, M., Slater, J., \& Desmarais, A. A. (2017). Student food insecurity at the University of Manitoba. Canadian Food Studies/La Revue canadienne des études sur l'alimentation, 4(1), 139-159. https://doi. org/10.15353/cfs-rcea.v4i1.204

Farahbakhsh, J. J. (2015). What is the food security status, self-rated health, and diet of students using a university-based food bank? [Master's thesis, University of Alberta]. ERA: Education \& Research Archive. https://era.library.ualberta.ca/ items/631f514b-fab7-451f-8380-fc7dc8edc015

Farahbakhsh, J., Ball, G. D., Farmer, A. P., Maximova, K., Hanbazaza, M., \& Willows, N. D. (2015). How do student clients of a university-based food bank cope with food insecurity? Canadian Journal of Dietetic Practice and Research, 76(4), 200-203. https://doi.org/10.3148/cjdpr-2015-020

Farahbakhsh, J., Hanbazaza, M., Ball, G. D., Farmer, A. P., Maximova, K., \& Willows, N. D. (2017). Food insecure student clients of a university-based food 
bank have compromised health, dietary intake and academic quality. Nutrition \& Dietetics, 74(1), 67-73. https://doi.org/10.1111/1747-0080.12307

Frank, L. (2018). "Hungry for an education": Prevalence and outcomes of food insecurity among students at a primarily undergraduate university in rural Nova Scotia. Canadian Journal of Higher Education, 48(2), 109-129. https://doi.org/10.47678/cjhe. v48i2.188112

Gallegos, D., Ramsey, R., \& Ong, K. W. (2014). Food insecurity: Is it an issue among tertiary students? Higher Education, 67(5), 497-510. https://doi. org/10.1007/s10734-013-9656-2

Government of Canada. (2020a). Building on success: International education strategy (2019-2024). https://www.international.gc.ca/education/strategy-2019-2024-strategie.aspx?lang=eng

Government of Canada. (2020b). Household food insecurity in Canada: Overview. https://www.canada.ca/en/health-canada/services/food-nutrition/ food-nutrition-surveillance/health-nutrition-surveys/ canadian-community-health-survey-cchs/household-food-insecurity-canada-overview.html

Hanbazaza, M., Ball, G. D., Farmer, A. P., Maximova, K., Farahbakhsh, J., \& Willows, N. D. (2017). A comparison of characteristics and food insecurity coping strategies between international and domestic postsecondary students using a food bank located on a university campus. Canadian Journal of Dietetic Practice and Research, 78(4), 208-211. https://doi.org/10.3148/cjdpr-2017-012

Hanbazaza, M., Ball, G. D., Farmer, A., Maximova, K., \& Willows, N. D. (2016). Filling a need: sociodemographic and educational characteristics among student clients of a university-based campus food bank. Journal of Hunger \& Environmental Nutrition, 11(4), 569-577. https://doi.org/10.1080/19320248.2 $\underline{015.1128864}$

Holloway, I. (1997). Basic concepts for qualitative research. Blackwell Science.

Horacek, T. M., \& Betts, N. M. (1998). Students cluster into 4 groups according to the factors influencing their dietary intake. Journal of the American Di- etetic Association, 98(12), 1464-1467. https://doi. org/10.1016/S0002-8223(98)00333-2

ICEF Monitor. (2014, February 17). Canada confirms new student visa regulations. http://monitor.icef. com/2014/02/canada-confirms-new-student-visa-regulations/

Jyoti, D. F., Frongillo, E. A., \& Jones, S. J. (2005). Food insecurity affects school children's academic performance, weight gain, and social skills. Journal of Nutrition, 135(12), 2831-2839. https://doi. org/10.1093/jn/135.12.2831

Kim, Y. (2001). Becoming intercultural: An integrative theory of communication and cross-cultural adaptation. Sage.

Laban, S., Jackson, E., Maynard, M., Loring, P.A. (2020, June 12). Student food insecurity: A problem before, during and after COVID-19. University Affairs. https://www.universityaffairs.ca/opinion/ in-my-opinion/student-food-insecurity-a-problembefore-during-and-after-covid-19/

Lee, S. D., Hanbazaza, M., Ball, G. D., Farmer, A., Maximova, K., \& Willows, N. D. (2018). Food insecurity among postsecondary students in developed countries: A narrative review. British Food Journal, 120(11), 2660-2680. https://doi.org/10.1108/BFJ08-2017-0450

Loopstra, R., \& Tarasuk, V. (2012). The relationship between food banks and household food insecurity among low-income Toronto families. Canadian Public Policy, 38(4), 497-514. https://doi. org/10.1353/cpp.2012.0048

Maroto, M. E., Snelling, A., \& Linck, H. (2015). Food insecurity among community college students: Prevalence and association with grade point average. Community College Journal of Research and Practice, 39(6), 515-526. https://doi.org/10.1080/10 $\underline{668926.2013 .850758}$

Maynard, M. S., Meyer, S. B., Perlman, C. M., \& Kirkpatrick, S. I. (2018). Experiences of food insecurity among undergraduate students: "You can't starve yourself through school." Canadian Journal of Higher Education, 48(2), 130-148. https://doi. org/10.47678/cjhe.v48i2.188121 
Mclntyre, L., Glanville, N. T., Raine, K. D., Dayle, J. B., Anderson, B., \& Battaglia, N. (2003). Do low-income lone mothers compromise their nutrition to feed their children? CMAJ, 168(6), 686-691. https:/l www.cmaj.ca/content/168/6/686.long

Mhurchu, C. N., Turley, M., Gorton, D., Jiang, Y., Michie, J., Maddison, R., \& Hattie, J. (2010). Effects of a free school breakfast programme on school attendance, achievement, psychosocial function, and nutrition: A stepped wedge cluster randomised trial. BMC Public Health, 10(1), 1-6. https://doi. org/10.1186/1471-2458-10-738

Morris, L. M., Smith, S., Davis, J., \& Null, D. B. (2016). The prevalence of food security and insecurity among Illinois university students. Journal of Nutrition Education and Behavior, 48(6), 376-382. https://doi.org/10.1016/j.jneb.2016.03.013

Muldoon, K. A., Duff, P. K., Fielden, S., \& Anema, A. (2013). Food insufficiency is associated with psychiatric morbidity in a nationally representative study of mental illness among food insecure Canadians. Social Psychiatry and Psychiatric Epidemiology, 48(5), 795-803. https://doi.org/10.1007/ s00127-012-0597-3

Olauson, C., Engler-Stringer, R., Vatanparast, H., \& Hanoski, R. (2018). Student food insecurity: Examining barriers to higher education at the University of Saskatchewan. Journal of Hunger \& Environmental Nutrition, 13(1), 19-27. https://doi.org/10.1080/193 $\underline{20248.2017 .1393365}$

Papadaki, A., Hondros, G., Scott, J. A., \& Kapsokefalou, M. (2007). Eating habits of university students living at, or away from home in Greece. Appetite, 49(1), 169-176. https://doi.org/10.1016/j.appet.2007.01.008

Patton-López, M. M., López-Cevallos, D. F., Cancel-Tirado, D. I., \& Vazquez, L. (2014). Prevalence and correlates of food insecurity among students attending a midsize rural university in Oregon. Journal of Nutrition Education and Behavior, 46(3), 209-214. https://doi.org/10.1016/j.jneb.2013.10.007

Pinstrup-Andersen, P. (2009). Food security: Definition and measurement. Food Security, 1(1), 5-7. https:// doi.org/10.1007/s12571-008-0002-y
Power, E., \& Dietitians of Canada. (2005). Individual and household food insecurity in Canada: position of dietitians of Canada. Canadian Journal of Dietetic Practice \& Research, 66(1), 43-46. https://doi. org/10.3148/66.1.2005.43

Pryor, L., Lioret, S., Van Der Waerden, J., Fombonne, É., Falissard, B., \& Melchior, M. (2016). Food insecurity and mental health problems among a community sample of young adults. Social Psychiatry and Psychiatric Epidemiology, 51(8), 1073-1081. https://doi.org/10.1007/s00127-016-1249-9

Sanchez-Serra, D., \& Marconi, G. (2018). Increasing international students' tuition fees: The two sides of the coin. International Higher Education, 14(92), 13-14. https://doi.org/10.6017/ihe.2018.92.10278

Sandelowski, M. (2000). Whatever happened to qualitative description? Research in Nursing \& Health, 23(4), 334-340. https://doi.org/10.1002/1098240x(200008)23:4<334::aid-nur9>3.0.c0;2-g

Silverthorn, D. (2016). Hungry for knowledge: Assessing the prevalence of student food insecurity on five Canadian campuses. Meal Exchange. http://mealexchange.com

Stewin, E. (2013). An exploration of food security and identity among international students studying in Guelph and Windsor, Ontario, Canada [Master's thesis, University of Guelph]. The Atrium. https:/l atrium.lib.uoguelph.ca/xmlui/bitstream/handle/10214/6640/Stewin Erika 201305 MA.pdf?sequence $=6$

Tarasuk, V., Dachner, N., Hamelin, A.-M., Ostry, A., Williams, P., Bosckei, E., Poland, B., \& Raine, K. (2014). A survey of food bank operations in five Canadian cities. BMC Public Health, 14(1), 1-25. https://doi.org/10.1186/1471-2458-14-1234

United States Department of Agriculture. (2020, September). Survey tools - Food security in the U.S. Economic Research Service. http://www.ers.usda. gov/topics/food-nutrition-assistance/food-securityin-the-us/survey-tools.aspx\#adult

Vahabi, M., \& Damba, C. (2013). Perceived barriers in accessing food among recent Latin American immigrants in Toronto. International Journal for Equity 
in Health, 12(1), 1-11. https://doi.org/10.1186/14759276-12-1

Wu, H., Garza, E., \& Guzman, N. (2015). International student's challenge and adjustment to college.

Education Research International, 2015(20), 1-9.

https://doi.org/10.1155/2015/202753

\section{Contact Information}

Noreen D. Willows

nwillows@ualberta.ca 